\title{
AUSTRALIAN JOURNAL OF ZOOLOGY
}

publish.csiro.au/zo

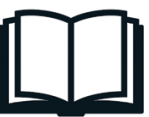

\section{SCOPE}

Australian Journal of Zoology is an international journal publishing contributions on evolutionary, molecular and comparative zoology. The journal focuses on Australasian fauna but also includes high-quality research from any region that has broader practical or theoretical relevance or that demonstrates a conceptual advance to any aspect of zoology. Subject areas include, but are not limited to: anatomy, physiology, molecular biology, genetics, reproductive biology, developmental biology, parasitology, morphology, behaviour, ecology, zoogeography, systematics and evolution.

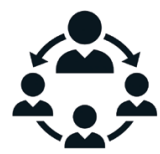

\section{AUTHOR BENEFITS}

- International reach and discoverability

- Indexing in a wide variety of relevant databases

- Professional copyediting for every paper

- Capture impact through citation tracking and Altmetrics

- Authors retain copyright

- Green Open Access with no embargo

- Gold Open Access compliant with major funders

- No page charges

- Rapid online publication ahead of issue release

- Eligible authors receive APC-free Open Access

\section{STAY IN CONTACT}

- publishing.ajz@csiro.au

- Join the conversation on social media using hashtag \#AusJZoology

- Sign up for free journals content emails publish.csiro.au/earlyalert

- Recommend the journal to your librarian publish.csiro.au/journals/recommend

LEARN MORE ABOUT THE JOURNAL

\section{Editor-in-Chief: \\ Paul Cooper \\ Australian National University}

Publishing Model: Hybrid Open Access options available

Frequency: 6 issues/year

Publishing since: 1953

eISSN: 1446-5698 (online)

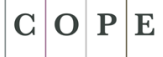

$$
\text { JM12789 }
$$

As a member of the Committee on Publication Ethics (COPE), Australian Journal of Zoology supports its core practices and is committed to transparency in scholarly publishing.

\section{SUBMIT YOUR ARTICLE ONLINE}

- Prepare: publish.csiro.au/zo/forauthors

- Submit: mc.manuscriptcentral.com/csiro-zo

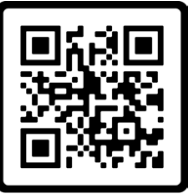

SCAN ME

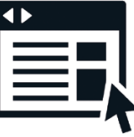

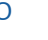




\section{JOURNAL METRICS}

\section{SPEED}

45 days from manuscript submission to first decision

23 days from manuscript acceptance to publication

\section{USAGE}

$\mathbf{5 6 , 3 2 5}$ downloads in 2021

535 Altmetrics mentions in 2021

\section{REJECTION RATE}

$\mathbf{4 3 \%}$ rejection rate in 2021

\section{IMPACT}

\# Ranking in area

125/176 in Zoology (Q3)

1.1 Impact Factor

1.2 5-Year Impact Factor

TC $\mathbf{2 1 9 2}$ Total Citations in 2021

JcI 0.5 Journal Citation Indicator

\subsection{CiteScore}

CS Highest percentile 46\% (241/448 Animal Science and Zoology)

SNIP

0.6 SNIP

Source Normalised Impact per Paper

SJR

$0.3 \mathrm{SJR}$

SCImago Journal Rank

h5

11 h5-index
Google Scholar index for papers published 2017-21

\section{ABOUT CSIRO PUBLISHING}

CSIRO Publishing operates as an editorially independent science publisher within Australia's premier research group, Commonwealth Scientific and Industrial Research Organisation (CSIRO), and has been publishing journals since 1948. Our internationally recognised publishing program includes journals, books and magazines and covers a wide range of scientific disciplines.

\section{PARTNER ORGANISATIONS}

he Association of Society Publishers

Copyright Clearance Center

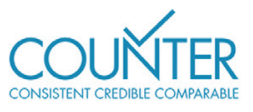

research4life
Crossref

Altmetric

$\$$ Dimensions

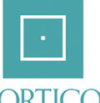

\section{publons}

